\title{
Biskupije Gornje Dalmacije na splitskim saborima 925. i 928. godine
}

IVICA PULJIĆ

Župni ured Neum

Trg Gospe od Zdravlja 1

$\mathrm{BiH}$ - 88390 Neum

E-pošta: don.ivica.puljic@tel.net.ba
UDK: 262.3(497.5 Dalmacija)"09"

Pregledni rad

Primljeno: 9. veljače 2018

Prihvaćeno: 30. svibnja 2018

\section{Sažetak}

Pobjedom kralja Tomislava nad Bugarima i dobra suradnja s papom Ivanom X. (914. - 928.) i Bizantom stvorili su nove okolnosti koje su omogućile pristup i uređenju crkvenoga ustroja na istočnoj obali Jadrana. Biskupi dalmatinskih gradova, na čelu sa splitskim nadbiskupom, bojali su se da ih kralj Tomislav ne podvrgne svom hrvatskom biskupu sa sjedištem u Ninu, koji je do tada vršio jurisdikciju u gotovo cijeloj hrvatskoj državi. To nisu htjeli prihvatiti pa su uložili mnogo truda da se samo obnovi antičko stanje u okviru Salonitanske metropolije. Ono im jamči i povratak negdašnjih prostora njihove jurisdikcije. Međutim, pod udarom načela da se sve vrati kako je bilo prije poremećaja crkvenog ustroja u vrijeme seobe naroda i ratova koji su uslijedili, osim Ninske biskupije našle su se u opasnosti i još neke. Na saboru 928. spomenute su tri biskupije istočno od Splita, Stonska, Dubrovačka i Kotorska, od kojih se, neočekivano, samo Stonskoj ne osporava pravo na opstojanje iako se ovom prigodom ona prvi put spominje u dokumentima. Kako je daleko većega značenja bio spor oko Ninske biskupije, sporu u vezi biskupija južno od Splita naša historiografija nije posvećivala puno pažnje.

Ključne riječi: Gornja i Donja Dalmacija; Dubrovačka biskupija; Stonska biskupija; Kotorska biskupija; Epidaurska biskupija; splitski sabori 925. i 928. 
Ivica Puljić - Biskupije Gornje Dalmacije na splitskim saborima 925. i 928. godine

\section{Gornja Dalmacija (Dalmatia Superior)}

Pojam Gornja Dalmacija (Dalmatia Superior) i Donja Dalmacija (Dalmatia Inferior) ima svoju povijest od ranocarskoga doba. Na prvi pogled ne zvuči logično da se područje južno od Dubrovnika zove "Gornja", a područje Splita i Zadra "Donja" Dalmacija. Podloga za podjelu mogao je biti reljef pokrajine, ali možda i prirodni fenomen morskih struja koje "teku" istočnom obalom Jadrana od juga prema sjeveru i time znatno olakšavaju plovidbu svih vrsta plovila od juga prema sjeveru što je u stara vremena bilo od velike važnosti. ${ }^{1}$

Prva u povijesti poznata zemljopisna podjela istočnojadranske obale dogodila se desete godine prije Krista, kada je Ilirik podijeljen na Gornji (Illyricum Superior) i Donji (Illyricum Inferior). Od II. stoljeća umjesto Ilirik (Illyricum) za pokrajinu se uglavnom upotrebljava naziv Dalmacija. U izvorima se i ona dijeli na Gornju i Donju Dalmaciju pa je pluralni oblik (Dalmatiae) veoma čest, gotovo redovit. Gornja Dalmacija uskoro dobiva naziv Praevalitana (Praevalis), ali se i dalje u vrelima češće upotrebljava pluralni oblik: Dalmacije (Dalmatiae, Dalmatiarum). ${ }^{2}$

Granica između Donje i Gornje Dalmacije tijekom povijesti znatno se mijenjala, kako u civilnom tako i u crkvenom pogledu. Tako npr. već car Konstantin VII. Porfirogenet (r. 905., naslijedio carsku krunu 913., umro 959.) kaže da je Dubrovnik bio metropola Budve, Kotora i Risna. ${ }^{3}$ Toma Arciđakon gornjodalmatinskim biskupima zove "sve biskupe od Dubrovnika na gore"t kada piše kako su se "gotovo svi" utopili u oluji putujući na sabor u Split, pa poimenično navodi kotorskoga, barskoga, ulcinjskoga i svačkoga biskupa! Za Dukljanina je "a loco Dalme... ad Valdevino" Bijela Hrvatska ili "Dalmatia inferior" te piše da je kralj područje od "Dalme usque Bambalonam civitatem, quod nunc dicitur Dyrrachium, Croatiam Rubeam vocavit quae et superior Dalmatia dicitur". Istu podjelu prati i Hrvatska kronika: "od

1 Pučanstvo susjedne Hercegovine i danas govori "gore u Dubrovniku" iako je grad na moru kao i Split.

2 Mino BAradA, "Dalmatia Superior", u: Rad JAZU, 270, Zagreb, 1949., str. 93 113; Dominik Mandić, Crvena hrvatska u svjetlu povijesnih izvora, ZIRAL, Chicago - Rim, 1973., str. 108-125.

3 U djelima De thematibus i Vita Basilii (prema: M. BARADA, nav. dj., str. 95, bilj. 12).

4 Tома ArнiĐakon, Kronika, "Čakavski sabor", Split, 1977., str. 45, pogl. XV. 
Dalme do Valdemina prozva Hrvate Bile, što su Dalmatini Nižnji. I još od mista Dalme do Bandalona grada, ča se sada zove Drač, dotla prozva Gornju Dalmaciju". ${ }^{5}$

U vrijeme održavanja splitskih sabora 925. i 928. godine, vrijeme vladavine kralja Tomislava, u spisima se također navodi pluralni oblik "Dalmacije", ${ }^{\mathrm{i}}$ isto tako u pismima papa Ivana X. 925. i Leona VI. 928. u kojima se potvrđuju zaključci saborâ. ${ }^{7}$ Dalo bi se zaključiti kako saborski oci drže sve biskupije na istok od Splita, tj. Stonsku, Dubrovačku i Kotorsku, ili barem Dubrovačku i Kotorsku, gornjodalmatinskim biskupijama. ${ }^{8} \mathrm{U}$ nešto kasnijem vremenu za metropolitansko pravo u Gornjoj Dalmaciji počet će višestoljetna borba Dubrovnika i Bara za metropolitansku vlast nad biskupima Gornje Dalmacije. ${ }^{9}$

5 Vladimir Mošin, Ljetopis Popa Dukljanina, Matica hrvatska, Zagreb, 1950., str. 54; Ferdo Šišić, Letopis popa Dukljanina, Srpska kraljevska akademija, Beograd, 1928., str. 306.

6 "Tempore Joannis pape sanctissimo consulatu peragente, in provintia Croatorum et Dalmatiarum finibus Tamisclao rege et Michaele in suis finibus presidente duce", u: NADA KLAIĆ, Historia Salonitana maior, posebna izdanja SANU, knj. 399, Odeljenje društvenih nauka, knjiga 55, Naučno delo, Beograd, 1967., str. 98 (dalje: HSM).

7 Potvrđujući odredbe sabora iz 925. papa Ivan X. upotrebljava pluralni oblik: "in ecclesiis Dalmatiarum" te kada piše kako ninski biskup sebi želi prisvojiti "primatum Dalmatiarum". Marko Kostrenčić - Jakov Stipišić - Miljen Šamšalović, Codex diplomaticus Regni Croatiae, Dalmatiae et Slavoniae, vol. I., (Diplomatički zbornik, I.), JAZU, Zagreb, 1967., str. 35 (dalje: CD, I.), Oblik "Dalmatiarum" upotrebljava i papa Leon VI. potvrđujući zaključke sabora iz 928. godine. $C D$, I., str. 38-39.

8 CD, I., str. 37.

9 O sporenju Dubrovnika i Bara za metropolitansko pravo postoje mnogobrojni kako izvori tako i literatura, primjerice: Stanoje Stanojević, Borba za samostalnost Katoličke Crkve u nemanjićkoj državi, Davidović, Beograd, 1912.; Ivan Marković, Dukljansko-barska metropolija, Tisak Antuna Scholza, Zagreb, 1902.; Ivan Jovović, Iz prošlosti Dukljansko-barske nadbiskupije, Nadbiskupski ordinarijat - Bar, Bar, 2004.; Dominik Mandić, "Osnutak dubrovačke metropolije", u: Rasprave i prilozi iz stare hrvatske povijesti, Hrvatski povijesni institut, Rim, 1963., str. 266-283; IvicA Puljıć, "Uspostava Dubrovačke metropolije", u: Tisuću godina Dubrovačke metropolije, Nediljko A. ANČIć (prir.), Crkva u svijetu Split, Dubrovnik, 2001., str. 15-56. 


\section{Crkvena organizacija u Dalmaciji i Hrvatskoj 925. i 928. godine}

U vremenima prije splitskih sabora događala su se velika politička previranja, vodili su se brojni ratovi i sklapani raznoliki savezi. U ratovima i sukobu hrvatskih vladara s Bizantom vlast dalmatinskih gradova kao i jurisdikcija njihovih biskupija svedena je gotovo na gradske zidine. ${ }^{10} \mathrm{O}$ uspješnom ratu humskoga kneza Mihaela, koji se jedini od velikaša imenom spominje na splitskim saborima, protiv Bizanta svjedoči natpis u Stonu na kojem stoji da je on hrabro izvojevao pobjedu nad "Grkom Pacifikom" i svim "Romanima". ${ }^{11}$ Slijedio je rat s moćnim bugarskim carem Simeonom nad kojim je kralj Tomislav izvojevao pobjedu koja je išla na ruku Bizantu pa je to dovelo do stvaranja novih političkih odnosa na istočnoj jadranskoj obali.

Spis, u povijesnoj znanosti poznat kao Historia Salonitana maior (HSM), kao uvod u održavanje sabora za to novo stanje, kratko kaže da se događa kada je papinsku službu obavljao Ivan X. (914. - 928.), u provinciji Hrvatâ i Dalmacijâ konzulsku vlast kralj Tomislav, a u svojim krajevima predsjedao knez $(d u x)$ Mihael. ${ }^{12}$ Je li Bizant Dalmaciju povjerio na izravnu upravu kralju Tomislavu u stvaranju prijateljskoga ozračja nakon pobjede nad Bugarima, povjesničari se ne slažu, ${ }^{13}$ iako bi se to moglo zaključiti iz nekih vijesti u saborskim spisima. Svakako je nakon ratova došlo do pregovora, u čemu sudjeluju i Bizant i Papa, pa i do određenih promjena u međudržavnim i crkvenim odnosima, u čemu je kralj Tomislav igrao važnu ulogu. Dalmatinski se biskupi nisu bez temelja bojali da ih kralj Tomislav podvrgne svome biskupu, jer je imao političku moć po kojoj je mo-

10 Papa Leon VI. potvrđujući zaključke sabora iz 928. godine piše za biskupe gradova da im se ne može svesti "parochia inter muros ciutitatis", CD, I., str. 39.

11 Više je autora dalo prijedlog čitanja spomenutoga natpisa. Najprihvatljiviji je ponudio Ivan Ostojıć, "O Mihajlovu natpisu u Stonu", u: Prilozi povijesti umjetnosti u Dalmaciji, XIV., Split, 1962., str. 34-39.

12 HSM, str. 98. Treba istaknuti pluralni oblik Dalmacijâ kao i to da Mihael u svojim krajevima predsjeda. Naša historiografija vrlo "šaroliko" piše o ovom vremenu: Usp. Tomislav Raukar, Hrvatsko srednjovjekovlje. Prostor, ljudi, ideje, Školska knjiga, Zagreb, 1997., str. 36-39; NADA KLAIĆ, Povijest Hrvata u srednjem vijeku, Globus, Zagreb, 1990., str. 77-78.

13 Usp. npr.: Ferdo Šišıć, Pregled povijesti hrvatskoga naroda, Nakladni zavod Matice hrvatske, Zagreb, 1975., str. 117; NADA KLAIĆ, Povijest Hrvata u ranom srednjem vijeku, Školska knjiga, Zagreb, 1971., str. 292; Ista: Povijest Hrvata u srednjem vijeku, str. $78 \mathrm{i}$ dr. 
gao to učiniti. O svojevrsnom političkom jedinstvu snažno govori upravo pristup organizaciji crkvenoga ustroja na cijelom području Hrvatske i Dalmacijâ, ${ }^{14}$ što je bilo svakako osnaženo potporom Bizanta i Pape. Dalmacija ipak ne će još zadugo postati sastavni dio hrvatske kraljevine.

Ipak kralj Tomislav nije, kako izgleda, mogao nametnuti crkveni ustroj po svojim željama na širim prostorima pa da pod jurisdikcijom njegova hrvatskog biskupa budu i biskupi dalmatinskih gradova. A u Mihaelovoj kneževini, po svemu sudeći, crkvenu je vlast vršio biskup Stona. Dalmatinski biskupi u saborskim zaključcima 925. jasno govore o svojoj opravdanoj bojazni da ih kralj u promijenjenim političkim okolnostima ne bi podvrgao svom biskupu. Zato su odmah krenuli u akciju da to po svaku cijenu spriječe. Pri tome unaprijed kažu da, ako "kralj i prvaci Hrvata" odluče svom biskupu podvrgnuti sve biskupije, u tom slučaju ne će nikakve crkvene poslove obavljati na području kraljevstva! ${ }^{15}$ Prema ustaljenim zakonima gotovo od dobivanja slobode za vrijeme cara Konstantina, a osobito u stoljećima koja su slijedila, crkveni je ustroj uglavnom slijedio onaj civilni pa bi, da je riječ samo o temi Dalmaciji, zadarski biskup imao pravo da se oko Zadra organizira metropolija. ${ }^{16}$ Međutim, dalmatinski biskupi nisu mogli na to ni pomišljati pa su izabrali drugi put, ne samo kako bi spriječili hrvatskoga kralja i velikaše da ih podvrgnu svome biskupu, nego još više kako bi pod svoju jurisdikciju vratili prostore koji su nekada bili u njihovoj jurisdikciji. Zato su upravo jednoglasno tražili da se obnovi stanje kakvo je bilo "u starini" (antiquitus), to jest da se zapravo samo obnovi Salonitanska metropolija sa sjedištem u Splitu. Zato se u saborskim spisima uporno naglašava to načelo "starine", što nije riječ o običnoj starini, nego o starini iz kasnoantičkoga doba, iz vremena negdašnje Salonitanske metropo-

14 N. Klaić, Povijest Hrvata u srednjem vijeku, od str. 78; Ista, Povijest Hrvata u ranom srednjem vijeku, od str. 293.

$15 C D$, I., zaključak br. XII., str. 32.

16 Takva je praksa bila u Crkvi već od Nicejskoga sabora 325. godine. Usp. DANIEL Mansi, "Concilium niceanum", I., can. 4, u: Conciliorum amplissima collectio, Paris, 1903., str. 679. Nada Klaić piše da je zadarski biskup "kao biskup metropole imao najviše prava na primat". N. KLAIć, Povijest Hrvata u srednjem vijeku, str. 80, 83. I papa Ivan X. pojedinačno oslovljava od svih sufragana uza splitskoga nadbiskupa samo zadarskoga biskupa: "...confratri nostro Ioanni, sancte salonitane ecclesie archiepiscopo, et Formino episcopo omnibusque suis sufraganneis episcopis", CD, I., str. 35. 


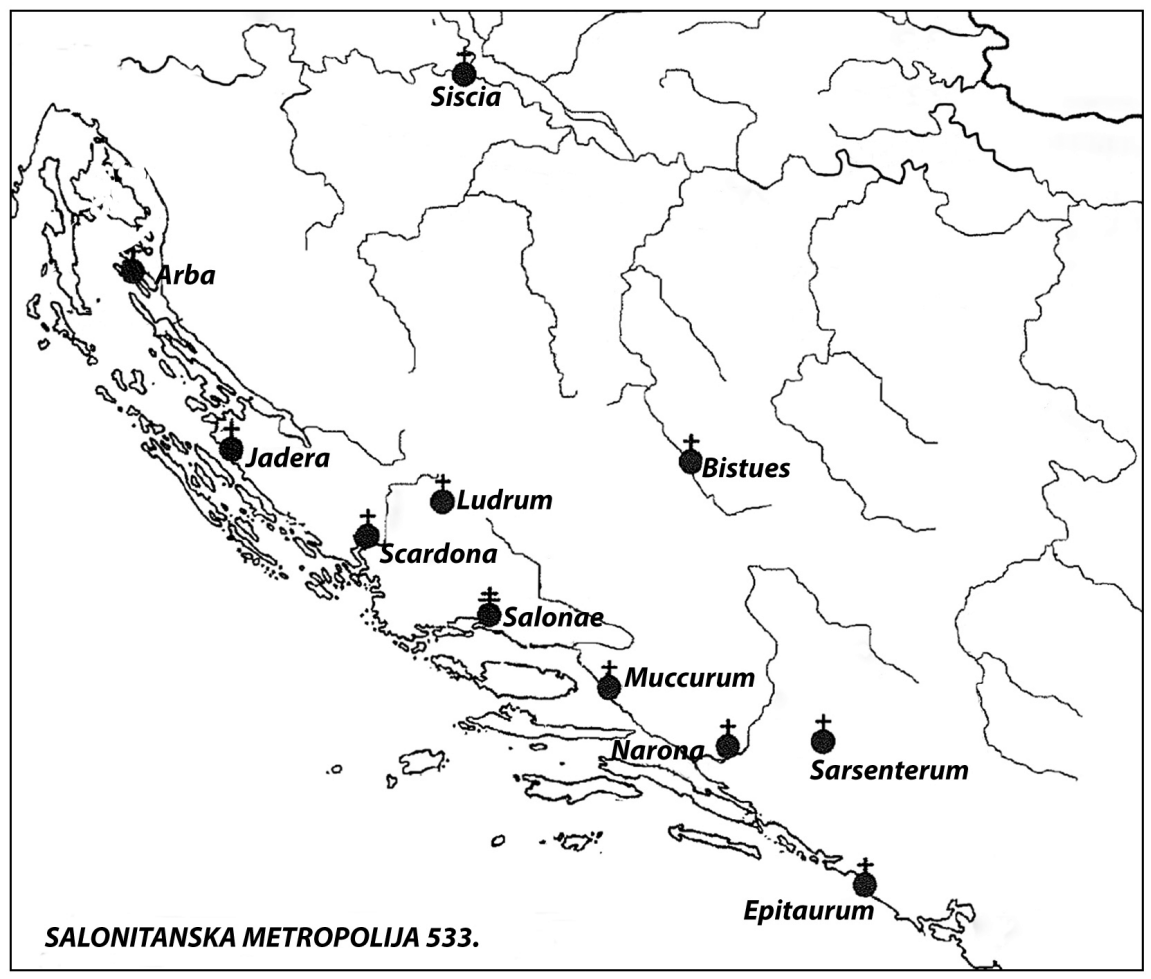

lije. U saborskim spisima se uostalom stalno govori o Salonitanskoj crkvi i nadbiskupu. Budući da su u HSM uklopljeni i akti pokrajinskih salonitanskih sabora iz 530. i 533. godine, ${ }^{17}$ opravdano je pretpostaviti da su upravo oni bili osnova za to. Obnovom Salonitanske metropolije ne samo da bi metropolitanska vlast bila u njihovim rukama, nego bi se postigao i onaj drugi cilj, svakoj bi se od njih vratila

17 HSM, str. 76-85. Usp. i Milan IvanišEvić, "Povijesni izvori", u: Salona christiana, Split, 1994., str. 159-161. Je li se na saborima raspravljalo i na temelju drugih izvora ne znamo. U zaključcima sabora 928. spominje se "Delminensis ecclesia" koje nema u aktima salonitanskih sabora, ali je 533. bilo određeno da područje "delminense" dobiva episcopus Muccoritanus pa je i ovdje moguće kao i u slučaju municipija Stantino, koji je temelj priznanja Stonske biskupije kao baštinice biskupije Sarsenterensis. O problemu postojanja biskupije Delminensis (kasnije Duvanjske biskupije) usp.: Ante Škegro, Na rubu opstanka - Duvanjska biskupija od utemeljenja do uključenja u bosanski apostolski vikarijat, Hrvatski institut za povijest, Zagreb, 2002.; Ante ŠKegro, "Tobožnja Delminijska biskupija. The alleged Diocese of Delminium", u: Opuscula archaeologica, 2007. - 2008., str. 283-302. 
jurisdikcija u hrvatskom zaleđu koju su imali u kasnoantičko doba. Saborski oci 925. godine izričito traže već u prvom zaključku da se sve vrati u stanje kakvo je nekada bilo. ${ }^{18}$ I papa Leon VI., potvrđujući zaključke sabora, piše 928. godine da se "parochia" biskupije ne može svesti na gradske zidine i u tom kontekstu poimenično spominje biskupije Osor, Rab, Dubrovnik i Split. ${ }^{19}$

\section{Stonska biskupija na saborima nije bila sporna ${ }^{20}$}

Na saboru iz 928. određuje se da biskup Nina izabere jednu antičku biskupiju: Skradinsku, Sisačku ili Duvanjsku, ili, na svoju propast, sve tri, jer Nin nije od starine (atiquitus) imao biskupa nego samo arhiprezbitera pod biskupovom jurisdikcijom. ${ }^{21} \mathrm{U}$ potvrdi zaključaka ovoga sabora papa Leon VI. određuje da ninski biskup Grgur uzme samo Skradinsku biskupiju jer njegova biskupija nije od starine nego je nastala u zemlji Hrvata "u kušnji vremena" (probitate temporum). ${ }^{22}$ Međutim, ako bi se obnovilo stanje kakvo je bilo u starini, u Salonitanskoj metropoliji, u pitanje se dovodi pravo na opstojnost još nekih biskupija. U zaključku sabora iz 928. navode se istočno od Splita biskupije Stonska, Dubrovačka i Kotorska. ${ }^{23}$ Sasvim neočekivano pravo na opstojnost po načelu starine ne osporava se jedino stonskom biskupu koji se ne spominje u doba Salonitanske metropolije. Dosljedno se iz ovoga mora svakako zaključiti da su saborski oci na te-

$18 C D$, I., str. 31.

$19 C D$, I., str. 39.

20 O Stonskoj biskupiji: Ante DračEvac, "Srednjovjekovna Stonsko-zahumska biskupija", u: Tisuću godina trebinjske biskupije, Studia vrhbosnensia, II., Sarajevo, 1988., str. 83-90; Ivica PuljIć, "Crkvene prilike u srednjovjekovnoj Humskoj zemlji", u: Povijest hrvatskog Počitelja, Humski zbornik, II., Čapljina - Zagreb, 1996., str. 88-150. Istı, "Stonsko-humska biskupija i počeci kršćanstva u Humskoj zemlji", u: Hercegovina, 8-9 (16-17), Mostar, 2002./2003., str. 23-30. Vinicije LuPIs, "Pregled povijesti stonske biskupije od osnutka do 1541. godine", u: Tisuću godina uspostave Dubrovačke (nad)biskupije, Crkva u svijetu Split, Dubrovnik, 2001., str. 197-217; Istı, "Povijesni pregled zahumske (stonske) biskupije od početaka do 1300. godine", u: Hum i Hercegovina kroz povijest, I., str. 133-154.

$21 C D$, I., str. 39.

22 Isto.

23 "...ecclesie vero alie, que in oriente habentur, id est Stagnensis, Ragusitana et Catharitana", CD, I., str. 37. 
melju nekih njima poznatih dokaza za Stonsku biskupiju držali da je bez sumnje postojala od starine (atiquitus). Jedino moguće objašnjenje toga postupka moglo bi biti u tome što se odlukom salonitanskoga metropolitanskog sabora iz 533. godine novoutemeljenoj biskupiji Sarsenterensis (Ecclesia Sarsenterensis) dodjeljuju bazilike u nekoliko municipija, među njima i u municipiju "Stantino". ${ }^{24}$ Slijedi logičan zaključak da se biskup biskupije Sarsenterensis u vrijeme seobe naroda samo sklonio na sigurnije mjesto vlastite biskupije, odnosno u svoju župu Ston, kao što su to činili i neki drugi biskupi (npr. biskup Epidauruma u Ragusium ili u Risan pa u Kotor, a nadbiskup Salone u Split unutar zidina Dioklecijanove palače). Tako je antička biskupija Sarsenterensis izgleda preživjela metež seobe naroda izmještajem sjedišta u prilično zaštićeni Ston koji nije bio na putovima prodora barbara. Od bule pape Benedikta VIII. iz 1022. godine ona se sve češće naziva biskupijom Huma (Zahumlja, Humske zemlje), što je područje koje je bilo pod jurisdikcijom biskupa Sarsenterensis.

Poseban status Stonske biskupije dade se izvesti i iz spomenute potvrde pape Leona VI. koji tvrdi da se jurisdikcija biskupije ne može svesti na gradske zidine pa poimenično nabraja biskupe: zadarskoga, osorskoga, rabskoga, dubrovačkoga i splitskoga, dok se stonski biskup ne spominje. Smije se zaključiti da se to nije na nju ni odnosilo. Naime, Ston je u prethodnim ratovima s Bizantom osvojio moćni knez $(d u x)$ Mihael (Višević), o čijoj pobjedi svjedoči, kako je već rečeno, spomenuti stonski latinski natpis. HSM navodi, što je također već rečeno, da Mihael u vrijeme kralja Tomislava "predsjeda u svojim krajevima". ${ }^{25}$ Vrlo je vjerojatno da je Mihael i sjedište svoje kneževine prenio u Ston i da je stonski biskup to prihvatio te nesmetano obavljao biskupsku službu, ne samo u Zahumlju, nego i u svim prostorima Mihaelove kneževine koja je sezala, po svemu sudeći, daleko na jug. Zato nije čudno što papa, među biskupima čija je jurisdikcija svedena na gradske zidine, navodi i Ragusium - Dubrovnik. Kako saborski spisi u drugim tekstovima više ne spominju poimenično kneza Mihaela, nego općenito pišu o "kralju i prvacima Hrvata", očito je među njima i Mihael, možda s nešto više autonomije i ovlasti.

24 O sjedištu kasnoantičke biskupije Sarsenterensis, koje je očito bilo u Stocu u istočnom dijelu Hercegovine, usp. Ivica Puljić - Ante ŠKegro, "The diocese of Sarsenterensis", u: Arheološki vestnik, 5, Ljubljana, 2006., str. 219-241; IvicA Puljić - Ante Škegro, "Sarsenterska biskupija", u: Povijesni prilozi - historical contributions, 25, Zagreb, 2006., str. 1-50.

25 HSM, str. 98. 
Da je on u sklopu Tomislavove hrvatske države, proizlazi i iz toga što papa Ivan X. 925. godine upućuje jedno zajedničko pismo Tomislavu i Mihaelu. Taj status kneza Mihaela posredno potvrđuje i mletački kroničar Ivan Đakon koji piše da je Mihael zarobio Petra, sina mletačkoga dužda Patricijaka kada je na povratku iz Konstantinopola htio proći "hrvatskim krajevima". ${ }^{26}$

Stonska će biskupija na saboru 928. izgubiti neka svoja novostečena područja, jer sabor određuje da kotorski i dubrovački biskupi međusobno pravedno podijele područje koje je očito prije u ratovima s Bizantom potpalo pod jurisdikciju stonskoga biskupa. Možda je tomu razlog da se Stonska biskupija češće naziva biskupijom Zahumlja, Huma nego Stona.

\section{Na saborima se raspravljalo o pravu na postojanje Dubro- vačke i Kotorske biskupije}

Dubrovačka i Kotorska biskupija ne spominju se u aktima salonitanskih metropolitanskih sabora 530. i 533. godine. Akte sabora iz 530. godine, uza salonitanskoga nadbiskupa Honorija II. potpisuju biskupi iadertinus (zadarski), arbensis (rabski), siscianus (sisački), epitauritanus (epidaurski - danas Cavtat), scardonitanus (skradinski), naronitanus (danas Vid kod Metkovića), bestoensis (o čijem se lociranju povjesničari ne slažu) i maktaritanski mactaritanus (čije je lociranje također još uvijek nesigurno) te neki salonitanski prezbiteri kao i prezbiter sarniensis (možda senjski). ${ }^{27}$ Akte sabora iz 533. godine potpisali su, uza salonitanskoga nadbiskupa Honorija II., također i biskupi Iadertinae ecclesiae (Zadarske), Arbensis ecclesiae (Rabske), Siscianae ecclesiae (Sisačke), Naronitane ecclesiae (Vid kod Metkovića), Bestoensis ecclesiae, Sarsenterensis ecclesiae, Muccorensis ecclesiae (Makarske) i Ludroensis ecclesiae te biskup Paulus episcopus. ${ }^{28}$

26 Franjo RačKI, "Documenta historiae chroaticae periodum antiqum illustrantia", u: Monumenta spectantia historiam Slavorum meridionalium, Academia scientiaarum et artiuum Slavorum meridionalium, Zagreb, 1877., str. 388.

27 Radoslav Dodig - Ante Škegro, "Akti crkvenih sabora održanih 530. i 533. u Saloni", u: Povijesni prilozi, 35, Zagreb, 2008., str. 16-17; Ante Škegro, "Akti Salonitanskih metropolitanskih sabora održanih 530. i 533. godine - analiza", u: Archaeologia Adriatica, 3, Zadar, 2009., str. 191-204, passim.

28 R. DODIG - A. ŠKEGRo, "Akti crkvenih sabora", str. 21-22. 
Na Salonitanskom saboru 533. ne spominju se biskupije Absarensis, ${ }^{29}$ Velclensis, Delminensis, Stagnensis, Ragusitana i Catharitana. Saborski spisi iz 928. godine drže, dakle, spornim postojanje Dubrovačke i Kotorske biskupije, a za ostale spomenute biskupije zakonito je postojanje priznato iako se ne spominju u spomenutim aktima salonitanskih sabora 530. i 533. godine, očito na temelju nekih drugih njima poznatih izvora... Možda su biskupi neke od njih Paulus i Savianus, ${ }^{30}$ kojima se ne navodi biskupija na saboru 533. godine. Svakako u novije vrijeme s velikom je sigurnošću dokazano da je Sarniensis ecclesia zapravo Senjska biskupija. ${ }^{31}$

Iako najnovija iskapanja i istraživanja govore o starijem vremenu nastanka Dubrovnika, ${ }^{32}$ on se u više starih izvora izravno ili neizravno smatra nasljednikom Epidauruma. ${ }^{33}$ Zato ne čudi činjenica što

29 Ova se biskupija spominje na sedmom ekumenskom, tj. Drugom nicejskom saboru, 787. godine. D. J. MANsI, Sacrorum conciliorum nova et amplissima collectio, Firenca i Venecija 1759. - 1798., sv. 13, str. 373-374; JEAN DARRouzÈs, "Listes épiscopales du concile de Nicée (787)", u: Revue des ètudes byzantines, 33 (1975.), str. 68, prema: RAdoslav Katičić, Uz početke hrvatskih početaka. Filološke studije o našem najranijem srednjovjekovlju, Književni krug, Split, 1993., str. 34.

30 HSM, str. 85

31 HSM, str. 85, bilj. 323; FERDo ŠIšIĆ, Priručnik izvora hrvatske historije, čest 1 (do godine 1107.), Naklada Kr. Hrv.-slav.-dalm. zemaljske vlade, Zagreb, 1914., na str. 161 potpis "Vitalis presbyter Sarniensis ecclesie" za koga u nekim rukopisima piše "sarnitensis" čita kao "Sarsenterensis ecclesie" kao i više drugih autora. Njegovo i mišljenja drugih autora prije i poslije njega vidi: ANTE ŠKEGRO, "Sarnienska dijeceza (Sarniensis Ecclesia)", u: Starohrvatska prosvjeta, III. serija - svezak 37, Split, 2010., str. 247-263; DARко Neкić, "Senjska biskupija u srednjem vijeku", u: Senjski zbornik, 24, Senj, 1997., str. 32-34.

32 Antun NičEtić, Nove spoznaje o postanku Dubrovnika: o njegovu brodarstvu i plovidbi svetoga Pavla, Dubrovnik, 2005. Usp. Ante Škegro, "The Diocese of Epitaurum - Ecclesia Epitauritana", u: Histria antiqua: časopis Međunarodnog istraživačkog centra za arheologiju. Journal of the International Research Centre for Archaeology, sv./vol. 18, Pula, 2009., str. 203-216; Ante ŠKegro, "Epitaurska biskupija (Ecclesia Epitauritana)", u: Zbornik radova Ivice Žile, Matica hrvatska - Ogranak Dubrovnik, Dubrovnik, 2011., str. 101-120.

33 Ravennatis Anonymi, Cosmographia et Gvidonis Geographica (ed. M. PinDER - G. PArthey), Aalen, 1962., IV., str. 16, 114: Anonimni Ravenski kozmogra donosi: "Epitaurum id est Ragusium", a Gvidonova Geografija: "Epitauron ubi nunc est Ratisium". Car Porfirogenet kaže da "Rausijci" drže "grad zvan Pitaura". Usp. Konstantin Porfirogenet, O upravljanju Carstvom (ur. Mirko MAĐOR), Dom i svijet, Zagreb, 2003., str. 69-71, 252-253. Bula pape Benedikta 
dubrovački biskup tvrdi kako je njegova biskupija zapravo biskupija Epidauritana i prema tomu ima pravo postojanja.

Epidaurum je vjerojatno naselje iz doba grčke kolonizacije naše obale kada više kolonija na našoj obali dobiva ime po imenima grčkih nositelja te kolonizacije (kao npr. Korčula, Vis, Hvar i dr.). Osim imenom s grčkim gradom Epidaurosom na Peleponezu (o čijoj važnosti dostatno govori kazalište s 14.000 sjedišta!) vjerojatno ga veže i štovanje božanstva Asklepiosa (lat. Aesculapius), ali nekih jačih dokaza za njegov razvoj prije dolaska Rimljana gotovo da i nema. ${ }^{34} \mathrm{Za}$ vrijeme vladavine Rimljana on se ubrzano razvija u gradsko naselja kojega kao putnu postaju uz jadransku obalu bilježe antički itinerari i mape te postaje središte širega područja. ${ }^{35}$ Rimska se vlast ovdje utvrdila barem od 135. godine, a osobito od 47. prije Krista. Uz brojne natpise i druge nalaze o njegovu značenju svjedoči gradski vodovod po kojemu i drugim kanalima kroz polje nose ime Konavli.

Kršćanstvo se na području Epidauruma ukorijenilo veoma rano, iako o tome nemamo pažnje vrijednih dokaza u nalazima. Ipak, ovu tvrdnju dostatno potkrjepljuje legenda o sv. Hilarionu (na cavtatskom i dubrovačkom području pod imenom Ilar, 291. - 371.) koja govori kako je taj svetac čudotvorac jedno vrijeme života proveo i u okolici Epidauruma. Životopis mu je napisao dvadesetak godina poslije njegove smrti i sv. Jeronim. Ovo dakako upućuje da je kršćanstvo na epidaurskom području bilo nazočno i vjerojatno već prilično orga-

VIII. iz 1022. naslovljena je "archiepiscopo Pitabritane sedis e ciuitate Labusedi", CD, I., str. 61-62. Najstariji dubrovački kroničar Milecije donosi najstariju dubrovačku tradiciju: "...ex Epuidauro... ubi nunc est urbs Rhagusina", NATKO Nodilo, u Monumenta historiam Slavorum meridionalium spectantia, XIV., str. 174. Dukljanin kaže: "Epitaurum quod nunc dicitur Ragusium", vidi: V. Mošin, nav. dj., str. 54; F. Šıšıć, nav. dj., str. 306; T. ArHiĐAкоn, Kronika, piše za stanovnike razorenog Epidauruma: "Sagradili su Dubrovnik i nastanili se u njemu", izd. Čakavski sabor, str. 37; HSM, str. 92 i dalje. Usp. i ŽELJKo RaPANić, "O početcima i nastajanju Dubrovnika. Naknadna razmišljanja", u: Starohrvatska prosvjeta, 40, Split, 2013., str. 81-126; Radoslav Katičić, "Aedificaverunt Ragusium et habitaverunt in eo. Tragom najstarijih dubrovačkih zapisa", u: Starohrvatska prosvjeta, 18, Split, 1988., str. 5-38.

34 Usp. Nenad Cambi, "Antički Epidaur", Dubrovnik, 3, 2006., str. 185-217; PETAR LISIČAR, "Prilozi o poznavanju Epitaura", u: Radovi Filozofskog fakulteta u Zadru, 4, Zadar, 1966., str. 25-43.

35 Ivo BoJAnovski, Bosna i Hercegovina u antičko doba, ANUBiH, Djela, knjiga LXVI., Centar za balkanološka ispitivanja, knjiga 6, Sarajevo, 1988., str. 76-87. 
nizirano tijekom druge polovice IV. stoljeća. ${ }^{36}$ Od dobivanja slobode kršćanstva, a osobito od Nicejskoga sabora 325. godine, Crkva nastoji, kako je rečeno, svoju organizaciju uskladiti s državnom, što se odredbama kasnijih pokrajinskih i općih sabora (osobito sardičkog iz 343. ili 347. godine) dosljednije provodi. Da se i u našim krajevima na to budno pazilo svjedoče akti i salonitanskih i splitskih sabora. Osobito se budno pazi na rang naselja u kome se uspostavlja sjedište biskupije i crkvene pokrajine metropolije. Za naš predmet od osobite je važnosti činjenica da spomenuti Salonitanski sabor 533. godine ističe kako su saborski oci budno razmotrili crkvene propise s obzirom na uspostavu biskupija, koje se ne osnivaju u malim mjestima ${ }^{37}$ da se ne bi omalovažio ugled i čast biskupa, ali i to da su još marliivije razmotrili ("diligentius pertractemus") u kojim se mjestima biskupi moraju posvetiti ("debeant consecrari"). ${ }^{38}$ Epidaurum se u rimsko doba brzo razvija u emporij "najjači između Neretve i Rhizonitskog zaljeva" ${ }^{39}$ pa je kao takav rano dobio status naselja u kome se "mora" uspostaviti biskupija, kao i u drugim većim gradovima u Dalmaciji. Prvi spomen Ecclesiae Epitaurane ipak je tek na Salonitanskom saboru 530. godine. Na saboru je sudjelovao, i akte potpisao, biskup Fabricianus. Epidaurski biskup se spominje i u pismima iz vremena pape Grgura I. Velikog (590. - 604.) i konfliktnih salonitanskih nadbiskupa Natalisa i Maksima. ${ }^{40}$

Seoba naroda je i za Epidaurum bila veoma razorna. Toma Arciđakon zgodno piše kako je Epidaurum opsjedanjem veoma oslabljen, i oslabljen zauzet, zauzet i pretvoren u pustos. ${ }^{41}$

36 A. ŠKegro, The Diocese of Epitaurum, str. 204.

37 Ovu odredbu doslovno ponavljaju saborski oci 925. pa se u II. zaključku kaže: "iuxta decreta partum non licet in modicis ciuitatibus uel villis episcopus statui...", $C D$, I., str. 31.

38 HSM, str. 82. Na tom saboru su posvećena tri nova biskupa "in Sarsentero, Muccuro et Ludro". Uza sve to marno preispitivanje saborskih otaca, papa Vigilije (537. - 555.) izgleda nije bio zadovoljan Honorijevim postupkom, kako svjedoči njegovo prijekorno pismo đakonima Rustiku i Sebastijanu iz 550. godine! Prema: M. IvanišEvić, nav. dj., str. 162.

39 I. BoJANOvski, nav. dj., str. 80.

40 A. Škegro, The Diocese of Epitaurum, str. 203-204.

41 T. ArHiĐAKon, Kronika, str. 37. 
Zbunjuje činjenica što saborski oci 925. godine tvrde za dubrovačkoga i kotorskoga biskupa da im je "mani(fe)ste una sedis". ${ }^{2}$ Ta "jedna" antička biskupska stolica za ova dva grada može biti jedino Epidaurska biskupija pa je očito i kotorski biskup kao i dubrovački branio svoje zakonito postojanje u nasljedstvu epidaurskoga biskupa. A prvi autentični spomen Kotorske biskupije jest sudjelovanje njezina biskupa Ivana na sedmom općem, drugom Nicejskom saboru 787. godine. ${ }^{43} \mathrm{U}$ vrijeme salonitanskih sabora Kotorska biskupija ili nije postojala ili je bila u sastavu neke druge metropolije. U oba slučaja na splitskim saborima morala se osloniti na neku biskupiju koja je na saborima 530. i 533. godine postojala u blizini Kotora, a bila je u sastavu Salonitanske metropolije. Na spomenutom Nicejskom saboru 787. sudjelovali su, uza spomenutoga kotorskog biskupa Ivana, i salonitanski nadbiskup Ivan te biskupi osorski i rapski. Među natpisima u Kotoru navodi se i natpis biskupa Ivana iz 805 . godine. ${ }^{44}$ Kotorski se biskup na splitskim saborima nije oslonio na neko vrelo iz vlastite povijesti jer se na splitskim saborima odlučuje o obnovi Salonitanske metropolije u kojoj nema spomena kotorskoga biskupa, a upravo se zbog toga nespominjanja ukida pravo ninskoga biskupa na postojanje pod tim imenom, bez obzira kada mu je utemeljena biskupija. Kotorski se biskup ne oslanja ni na Risansku biskupiju jer se ni ta biskupija ne spominje u sastavu Salonitanske metropolije pa joj ni to ne bi koristilo. Osobito je zanimljivo što se Kotorska biskupija ne naslanja na Maktaritansku biskupiju čiji biskup Viktor potpisuje akte salonitanskih sabora 530. godine, a Marcellus akte iz 533. godine, ${ }^{45}$ jer se u novo doba poistovjećuje Catharitana (Kotorska) i Mactaritana/Martaritana ecclesia. ${ }^{46}$

$42 C D$, I., str. 31.

43 R. Katičıć, nav. dj., 27-34; Ante ŠKegro, "Maktaritanska/Martaritanska biskupija", u: Bosna franciscana, 32, Sarajevo, 2010., str. 131-132.

44 Usp. A. ŠKegro, Mataritanska/Martaritanska biskupija..., str. 134 i bilj. 127 na istoj stranici.

45 HSM, str. 81, 85.

46 Ante Škegro, "The Diocese of Mactaris/Martaris (Ecclesia Mactaritana/ Martaritana)", u: Zbornik radova sa Znanstvenog skupa Stjepan Gunjača i hrvatska srednjovjekovna povijesno-arheološka baština, 1, u povodu 100. obljetnice rođenja akademika Stjepana Gunjače, Split, 2009., izdanje: Muzej hrvatskih arheoloških spomenika, 2010., str. 195-205. 
Jurisdikcija se kotorskoga i dubrovačkoga biskupa inače u nekoliko navrata kroz povijest ispreplitala, pa i sam se Cavtat dugo nalazio u jurisdikciji kotorskoga biskupa. Ima mišljenja da se zapravo biskup iz Epidauruma najprije sklonio u Risan pa u Kotor. ${ }^{47}$ Vjerojatno je to na saborima i tvrdio kotorski biskup na temelju nekih dokaza koje je prikazivao ili na temelju tradicije.

Da su saborski oci prijeporu Dubrovnika i Kotora posvetili veliku pažnju, svjedoči i to što su o tome donijeli rješenje u VIII. zaključku, a o biskupu Nina tek u XI.-XII.! U članku VIII. saborski oci donose prilično diskutabilno rješenje. U njemu se kaže da je, kada je riječ o dubrovačkom i kotorskom biskupu, riječ o jednoj biskupiji s dva biskupa. Određuje se da tu (jednu) biskupiju sada oba biskupa pravedno podijele, sačuvavši joj ipak jedinstvo na taj način što će po smrti jednoga biskupa onaj drugi njome upravljati dok se imenuje novi. ${ }^{48} \mathrm{Da}$ saborski oci spase obje biskupije posegnuli su, dakle, za rješenjem koje se ne temelji ni na teologiji ni na praksi Crkve. Prema svetopisamskom tekstu biskupa se drži "anđelom" određene Crkve (usp. Otk 1-3), a u crkvenoj praksi biskupovo jedinstvo s biskupijom je zaručničko. Tako ova formulacija da jedna biskupija (saborski oci kažu da to ostaje i dalje na neki način na snazi) ima dva biskupa! Slikovito to znači da zaručnica ima dva zaručnika! Uvijek je biskup bio biskupom samo jedne biskupije ili dviju ako su kanonski ujedinjene u jednu. Uza svoju biskupiju biskup je mogao upravljati i drugom biskupijom, ali ne kao njezin biskup nego kao upravitelj. Spomenuto neuobičajeno objašnjenje saborskih otaca do te je mjere neuobičajeno da neki povjesničari ne daju latinskom tekstu dostatnu pažnju pa govore kako je riječ o jednom biskupu za dvije biskupije! Zaključak jasno govori o dotadašnjem postojanju dvojice biskupa (dubrovačkoga i kotorskoga) na samo jednoj priznatoj biskupskoj stolici za obojicu. ${ }^{49}$

47 "Rose, koje dubrovačke papinske povelje spominju uvijek uz Kotor (civitatem Catharinensem seu Rose), možda je bio prva etapa u seljenju epidaurskog biskupa iz Epidauruma u zaštićeni Kotor." Milorad Medini, u: Starine dubrovačke, Dubrovnik, 1935., str. 193.

48 "VIII. De episcopis Ragusitano et Catharitano, quorum mani(fe)ste una sedis dignoscitur, ipsam diocesim equa lance inter se diuidant ita, ut si unus dicte ecclesie pastor obierit, donec ordinetur episcopus residens ipsius ecclesie ecclesiasticarum curam geret". CD, I., str. 24.

49 Foretić npr. piše da je do tada Dubrovnik i Kotor jedna biskupija sa sjedištem u Dubrovniku, a sada se dijeli u dvije: "Fino allora Ragusa e Cattaro facevano un solo vescovato, evidentemente colla sede a Ragusa, e da allora in poi se devono 


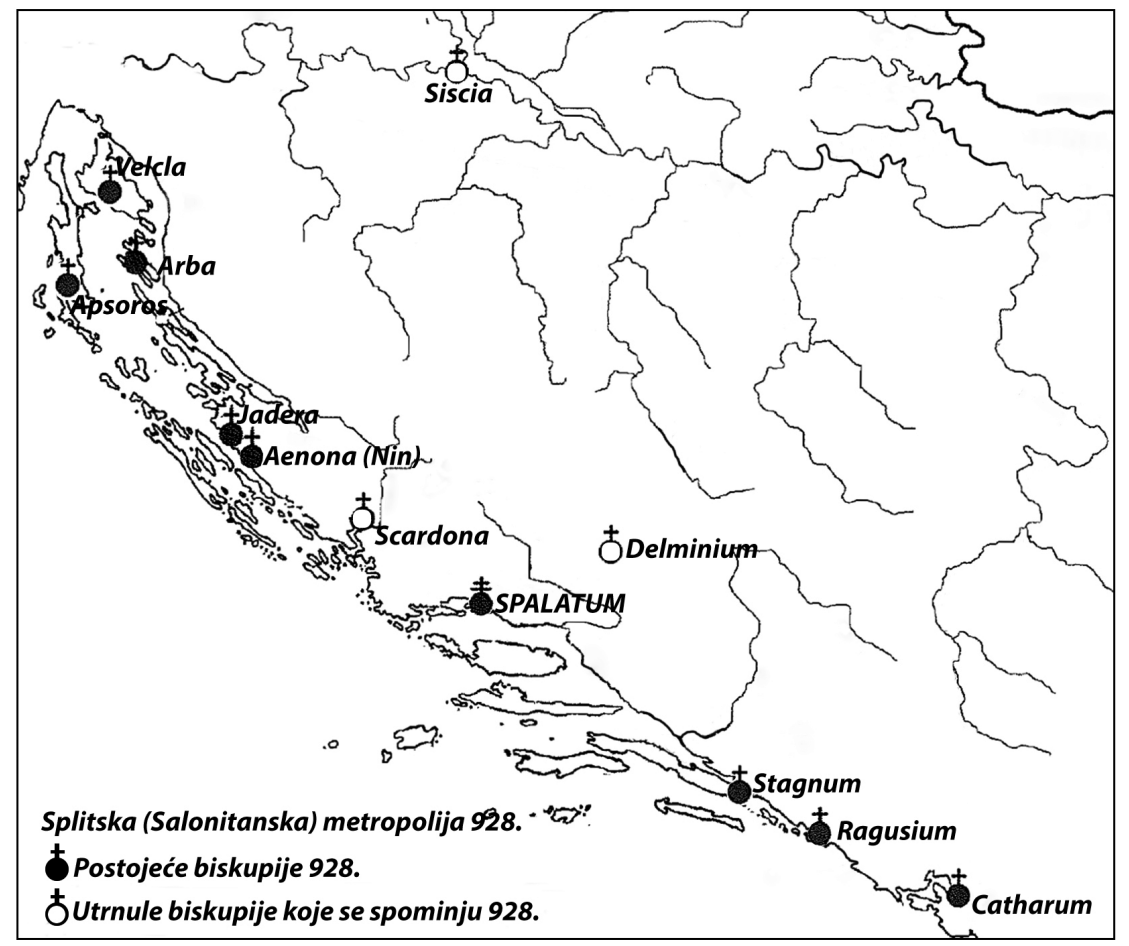

Tako se poimenično u aktima Splitskoga sabora iz 928. godine uza Splitskoga metropolitu poimenično navode nesporne biskupije Arbensis, Velclensis, Absarensis, ugašene Sisciana, Scardonitana, Delminensis te sporne Ragusitana i Catharitana čije je postojanje ozakonjeno.

Papa Leon VI. je iste godine potvrdio zaključke sabora iz 928. godine, ${ }^{50}$ pa je time na neko vrijeme riješen problem crkvenoga ustroja $u$ Dalmaciji i Hrvatskoj, ali samo do novih sporova s Bizantom koji će inicirati uspostavu novih biskupija i osobito višestoljetna sporenja Dubrovnika i Bara za sufragane i metropolitansko pravo nad biskupijama u Gornjoj Dalmaciji.

dividere in due vescovati..." Vinko Foretić, "La Chiesa di Ragusa (Dubrovnik) in rapporti alla chiesa di Spalato (Split)", u: Vita religiosa morale e sociale ed i concili di Split (Spalato) dei secc. X-XI, Padova, 1982., str. 408.

50 CD, I., str. 38-39. 


\section{Dioceses of Upper Dalmatia at the Church Councils of Split in 925 and 928}

\section{Summary}

The victory of King Tomislav over Bulgaria resulted in good relations between Croatia and Byzantium, which made it possible for the Church to achieve unity about the establishment of a unique church province in Dalmatia and Croatia. The Dalmatian bishops reasonably feared that the empowered King Tomislav, who after the victory over the Bulgarians gained the affection of Byzantium, and the title of "consul", according to HSM, would subjugate them to his Croatian bishop in Nin, whose jurisdiction during the previous conflicts with Byzantium spread almost to the city walls of some dioceses. In the area where, according to church acts, duke $(d u x)$ Mihael (Visevic) ruled with a certain autonomy, the same position to the bishop of Nin in the north was to be held by Mihael's bishop of Ston, which reduced the jurisdiction of the Bishop of Dubrovnik and Kotor to the narrow city region. Although, according to the positive church and state regulations, the ecclesiastical organization was followed by the civilian one, Dalmatian bishops did not require the establishment of the ecclesiastical province around Zadar, the capital city of Dalmatia, which they certainly would not have gained anyway, so they put all their efforts to establish a new church structure in Croatia and Dalmatia (Upper and Lower) gathered around the Archbishop of Split as the successor of the ancient Salona. Returning to the ancient position (antiquitus) would bring them even more desirable convenience: restoring jurisdiction over the wider territories of the Croatian state that were lost at the time of hostilities with Byzantium. That is why Dalmatian bishops persistently sought from Popes John X and Leo VI to just rebuild the late antique Salonitan metropoly, in which they finally succeeded. However, there was a new difficulty because some of the existing dioceses were not mentioned under the name of Salonitan metropoly, i.e. to the east of Split there were three dioceses mentioned: Ston, Dubrovnik and Kotor. Unexpectedly, the right to exist was not questioned only to the Diocese of Ston, which, by the way, was mentioned here for the first time in an authentic document. It can hardly be interpreted differently except that it was clear to the Council Fathers that it was, actually, the diocese of Sarsenterensis to which Ston was assigned on the occasion of 
its founding in 533, and in which his bishop withdrew during the migrations.

Since the Dubrovnik and Kotor bishops were not mentioned as the suffragans of the ancient Salonitan Metropoly at the Salonitan councils in 530 and 533, the bishops of these two cities struggled for the jurisdiction over an ancient diocese within the Salonitan metropoly, which could only be Epitaritan diocese. The jurisdiction was endorsed to both bishops with a somewhat unusual formulation that it was, actually, a diocese with two bishops which they now needed to share justly preserving its unity, so that after the death of one of the bishops the other may govern the diocese until the new bishop is appointed. Thus, all disputes were resolved and a new church structure was established in Dalmatia and Croatia around the archbishop of the metropoly in Split, until some new times and wars when the situation would change again.

Keywords: Upper and Lower Dalmatia; Dubrovnik Diocese; Ston Diocese; Kotor Diocese; Epidaurus Diocese; Church Councils of Split in 925 and 928. 